\title{
DASAR KEWENANGAN PEMERINTAH DAERAH KABUPATEN BADUNG DALAM MEMBERIKAN STANDAR PELAYANAN BAGI PEREMPUAN DAN ANAK KORBAN KEKERASAN
}

\author{
By \\ Anak Agung Istri Ari Atu Dewi \\ ariatudewi@gmail.com \\ Faculty of Law Udayana University
}

\begin{abstract}
Base on Article 28 G paragraph (1) The Constitution of the Republic of Indonesia to declare, that every person has the right to protection of self, family, material, dignity, and property under his control, and has the right to feel secure and protection from threats to do or not to do that is a human right. In addition, under Article 20 of act Child Protection to regulate that the State, government, society, family, and the parents are obliged responsible for the implementation of child protection. In article 5 of act on the Elimination of Domestic Violence to declare that every person is prohibited from domestic violence against people in the scope of the household by means of: physical violence; psychological violence; sexual violence; or neglect of household.

Based on the reality that exsistence of women and children are the group who are becoming victims of violence. Many factors contribute to the violence against women and children, among which is a factor of a patriarchal culture that is still views women is lower than in men. Another thing is also very influence violence as a false perception of violence which considers that violence as a matter of course, and the rights of the offender.

The purpose of research is to determine the authority of local government in providing protection for women and children victims of violence. So, want to know the forms and mechanisms of a given service standards Badung regency administration especially to women and children victims of violence. Specific targets to be achieved is to provide information to the public that is legally local governments have the authority to provide service standards and to determine also whether local governments already have a minimum service standards and other forms of care is given to women and children victims of violence, given the many women and children victims of violence have not got a good service or minimum service as a form of protection for women and children victims of violence. The method is normative research.

Base on discussion can be presented, the first, that authority Badung Government in providing service standards for women and children victims of violence. That service standards has been regulated in act Number. 15 of 2013, that is the title of act the Protection of Women and Children Victims of Violence. Second, that the standard services forms of Badung Government have five (5) types of shapes minimum service standards.
\end{abstract}

Keyword : Authority, Service Standards, women and children Violence 


\section{PENDAHULUAN}

\subsection{Latar Belakang Masalah}

Berdasarkan realita, bahwa keberadaan perempuan dan anak merupakan kelompok rentan yang sering menjadi korban kekerasan. Banyak faktor yang mempengaruhi sehingga terjadinya kekerasan baik terhadap perempuan dan anak tersebut. Salah satu di antaranya adalah dipengaruhi oleh faktor budaya patriarki. Budaya Patriarki dimaksud secara umum masih sering berlaku dalam kehidupan masyarakat, yaitu memandang perempuan lebih lemah dibandingkan lakilaki. Hal lain sangat berpengaruh terjadinya kekerasan. Faktor lain yang juga berpengaruh adalah masih ada persepsi yang salah tentang kekerasan, yang mana menganggap bahwa kekerasan sebagai hal yang biasa dan merupakan hak dari pelaku.

Secara yuridis dalam Pasal $28 \mathrm{G}$ ayat (1) Undang-Undang Dasar Negara Republik Indonesia Tahun 1945 menyatakan bahwa setiap orang berhak atas perlindungan diri pribadi, keluarga, kehormatan, martabat, dan harta benda yang berada di bawah kekuasaannya, serta berhak atas rasa aman dan perlindungan dari ancaman ketakutan untuk berbuat atau tidak berbuat sesuatu yang merupakan hak asasi. Selain itu dalam Pasal 20 UU Nomor 35 Tahun 2014 tentang Perubahan atas Undang-Undang Nomor 23 Tahun 2004 tentang Perlindungan Anak, menegaskan bahwa Negara, pemerintah, Pemerintah Daerah, masyarakat, keluarga, dan orang tua atau wali berkewajiban dan bertanggungjawabterhadappenyelenggaraan perlindungan anak. Selanjutnya UndangUndang tentang Penghapusan Kekerasan Dalam Rumah Tangga yaitu UndangUndang Nomor 23 Tahun 2004, Dalam Pasal 5 ditegaskan, bahwasannya setiap orang dilarang melakukan kekerasan terhadap orang dalam lingkangan rumah tangganya dengan cara: melakukan kekerasan fisik, kekerasan psikis, kekerasan seksual dan melakukan penelantaran terhadap rumah tangga.

Kekerasan Terhadap Perempuan Di Kabupaten Badung Menurut Jenis Ke Kerasan Tahun 2009

\begin{tabular}{|c|l|c|}
\hline NO & JENIS-JENIS KEKERASAN & JUMLAH \\
\hline 1 & KEKERASAN FISIK & 37 \\
\hline 2 & KEKERASAN PSIKIS & 12 \\
\hline 3 & SEKSUAL & 9 \\
\hline 4 & EKSPLOITASI & 0 \\
\hline 5 & PENELANTARAN & 6 \\
\hline 6 & LAIN - LAIN & 2 \\
\hline & JUMLAH & $\mathbf{6 6}$ \\
\hline
\end{tabular}

SUMBER : POLRES BADUNG DAN POLTABES DPS

Tindak Kekerasan terhadap Anak di Kabupaten Badung menurut bentuk bentuk kekerasan dalam tahun 2006 2007

\begin{tabular}{|c|l|c|c|}
\hline NO & \multicolumn{1}{|c|}{$\begin{array}{c}\text { JENIS TINDAK } \\
\text { KEKERASAN }\end{array}$} & $\mathbf{2 0 0 6}$ & $\mathbf{2 0 0 7}$ \\
\hline 1 & Perbuatan Cabul & 3 & 3 \\
\hline 2 & Persetubuhan dengan Anak & 1 & 4 \\
\hline 3 & $\begin{array}{l}\text { Melarikan Anak di Bawah } \\
\text { Umur }\end{array}$ & 4 & 0 \\
\hline 4 & Penghinaan & 0 & 0 \\
\hline 5 & $\begin{array}{l}\text { Membuat Perasaan Tidak } \\
\text { Menyenangkan }\end{array}$ & 0 & 0 \\
\hline 6 & penganiayaan & 0 & 2 \\
\hline 7 & Penelantaran Anak & 0 & 1 \\
\hline 8 & Pemerkosaan & 0 & 0 \\
\hline 9 & Eksploitasi secara Seksual & 8 & 11 \\
\hline & \multicolumn{2}{|l}{} \\
\hline & JUMLAH & & \\
\hline
\end{tabular}

Berdasarkan data Kabupaten Badung yang disajikan di atas secara jelas menunjukan terjadinya fenomena kekerasan 
yang dialami perempuan dalam sedikit banyak terkait dengan konstruksi sosial yang melahirkan relasi yang berbeda antara laki-laki dengan perempuan. Konstruksi sosial tersebut terbentuk di dalam budaya masyarakat yang diwarnai nilai-nilai yang cenderung patriarkhis. Struktur budaya masyarakat seperti ini sering kali mengakibatkan terjadinya dominasi dan perlakuan yang diskriminasi terhadap kaum perempuan yang dilakukan oleh kaum laki-laki, yang nantinya mengakibatkan hambatan bagi kemajuan kaum perempuan.

Terkait dengan pemaparan data di atas , Negara dalam hal ini Pemerintah Daerah wajib melindungi perempuan dan anak korban kekerasan. Salah satu aspek perlindungan adalah bahwa Pemerintah Daerah Kabupaten wajib memberikan standar pelayanan kepada perempuan dan anak yang mendapatkan kekerasan. Hal ini dimaksudkan untuk memberikan aspek perlindungan kepada pihak perempuan dan anak korban kekerasan.

Berdasarkan pemaparan di atas, menjadi penting untuk dilakukan penelitian mengenai pengaturan standar pelayanan minimal yang diperoleh perempuan dan anak korban kekerasan dan bentuk bentuk pelayanan yang disediakan oleh negara.

Berdasarkan alasan-alasan tersebut, bahwa penelitian ini penting dan relevan untuk dilakukan yaitu untuk mencari suatu kebenaran dan kepastian tentang kewenangan Pemerintah Daerah Kabupaten Badung dalam memberikan perlindungan terhadap perempuan dan anak korban kekerasan serta ingin mengetahui bentuk-bentuk maupun mekanisme standar pelayanannya. Oleh karena itu peneliti berketetapan hati untuk mengangkat menulis sebuah karya ilmiah dalam bentuk jurnal ilmiah yang berjudul DASAR KEWENANGAN PEMERINTAH DAERAH KABUPATEN BADUNG DALAM MEMBERIKAN STANDAR PELAYANAN BAGI PEREMPUAN DAN ANAK KORBAN KEKERASAN.

\subsection{Rumusan Masalah}

Berdasarkan pemaparan dalam latar belakang di atas maka dapat dirumuskan suatu permasalahan sebagai berikut :

1. Bagaimanakah kewenangan

Pemerintah Daerah Kabupaten Badung dalam pemberian standar pelayanan bagi perempuan dan anak yang menjadi korban kekerasan?

2. Apa sajakah bentuk-bentuk standar pelayanan minimal yang diberikan Pemerintah Daerah Kabupaten Badung bagi perempuan dan anak yang menjadi korban tindak kekerasan?

\subsection{Studi Pustaka}

Untuk membahas permasalahan di atas maka akan dikemukaan tinjauan pustaka sebagai berikut :

\subsubsection{Konsep kewenangan}

Secara konseptual istilah wewenang atau kewenangan dalam bahasa belanda dapat disebut "bevoegdheid" (yang berarti wewenang atau berkuasa). Mendasarkan pada pendapat Atmosudirdjo antara kewenangan (authority, gezag) dan wewenang (competence, bevoegheid) perlu dibedakan. Walaupundemikiandalampraktik, pembedaa tersebut tidak selalu dapat dirasakan. Dapat dipahami bahwa kewenangan merupakan kekuasaan formal yaitu kekuasaan dimaksud berasal dari kekuasaan legislative (pemberian Undang-Undang) atau dari kekuasaan 
Eksekutif administrative. ${ }^{1} \quad$ Kewenangan mempunyai kedudukan yang penting dalam penyelenggaraan pemerintahan, yang mana bahwa kewenangan tersebut mengandung hak dan kewajiban. Mendasarkan pada doktrin P. Nicolai bahwa Kewenangan adalah :

Het vermogen tot het verrichten van bepaalde rechtshandelingn (handeling die op rechtsgevoleg gericht zijn en dus ertoe strekken dat bepaalde rechtsgovelgen onstaan of teniet gaan). Een recht houdt in de (rechten gegeven) aanspraak op het verrichten van een handeling door een ander. Een plicht impliceert een verplichting om een bepaalde handeling te verrichten of na te laten. ${ }^{2}$

Dalam terjemahannya dapat dipahami bahwa kewenangan merupakan kemampuan untuk melakukan tindakan hukum tertentu (yaitu tindakan-tindakan yang dimaksudkan untukmenimbulkanakibat-akibathukum, dan mencakup mengenai timbul dan lenyapnya akibat hukum). Hak merupakan kebebasan untuk melakukan tindakan (melakukan tindakan tertentu atau menuntut pihak lain untuk melakukan tindakan tertentu). Kewajiban dimaksud memuat keharusan untuk melakukan tindakan tertentu).

Selanjutnya menurut Indroharto menyatakan bahwa wewenang tersebut dapat diperoleh melalui atribusi, delegasi dan mandat. Penjelasan masing-masing

Prajudi Atmosudirjo,1994, Hukum Administrasi Negara, Cetakan Kesepuluh, Ghalia Indonesia, Jakarta, hlm.78.

2 Ridwan HR, 2006, Hukum Administrasi Negara, PT. Raja Grafindo Persada, Jakarta, hlm.102. wewenang tersebut adalah sebagai berikut:

a. Wewenang yang diperoleh secara atibusi, yaitu pemberian wewenang pemerintahan yang baru oleh suatu ketentuan dalam peraturan perundangundangan. Jadi, disini dilahirkan/ diciptakan suatu wewenang pemerintah yang baru.

b. Wewenang delegasi adalah pelimpahan wewenang pemerintahan secara atributif kepada Badan atau Jabatan TUN lainnya. Oleh karena itu, suatu delegasi selalu didahului oleh adanya suatu atribusi wewenang.

c. Pada mandat, disitu tidak terjadi suatu pemberian wewenang baru maupun pelimpahan wewenang dari Badan atau Jabatan TUN yang satu kepada yang lain. ${ }^{3}$

\subsubsection{Konsep perempuan dan anak}

Pembaharuan hukum telah terjadi, ditandai oleh adanya berbagai instrument hukum yang menjamin kesetaraan dan keadilan bersumber dari beberapa kovensi internasional, hukum positif nasional, termasuk yurisprudensi dimana perempuan mendapatkan keadilan. Pengakuan dan perlindungan hak-hak perempuan lebih eksplisit dituangkan dalam CEDAW (Convention on the Elimination of All Forms of Discrimination Against Women). Lahirnya CEDAW merupakan awal momentum gerakan hak asasi perempuan yang lebih lanjut akan mewarnai gerakan-gerakan perempuan di forum internasional, nasional bahkan daerah (local). Dalam konvesi $C E D A W$ ini sangat menentang terjadinya

Indroharto, 1993, Usaha memahami Undang-Undang tentang Peradilan Tata Usaha Negara, Pustaka Harapan, Jakarta, hlm.90. 
diskriminasi terutama terhadap perempuan. Diskriminasi terhadap perempuan merupakan pelanggaran terhadap prinsip persamaan hak dan penghormatan terhadap martabat manusia. Bagian I dari konvensi $C E D A W$ memuat prinsip-prinsip konvensi diantaranya: 1) Prinsip non diskriminasi, 2) Prinsip persamaan (Keadilan substansi), 3) Prinsip kewajiban Negara. ${ }^{4}$

Selanjutnya Anak merupakan harapan suatu bangsa dimasa yang akan datang, oleh karena itu hak-hak yang harus diperoleh seorang anak adalah hak-hak yang berdasarkan hukum dan peraturan perundang-undangan yang berlaku. Perlindungan hukum terhadap anak dapat dipahami sebagai upaya perlindungan hukum terhadap berbagai kebebasan yang merupakan hak asasi anak (fundamental rights and freedoms of children) serta terpenuhinya berbagai kepentingan yang berkaitan dengan kesejahteraan anak. ${ }^{5}$

\subsubsection{Konsep kekerasan :}

Kekerasan dalam kamus bahasa Indonesia adalah sesuatu yang berarti keras. Dengan demikian kekerasan merupakan perbuatan seseorang yang membuat atau menyebabkan kerusakan fisik,maupun psikis. ${ }^{6}$

\section{Berdasarkan pada Undang-} undang Nomor 23 tahun 2004 tentang Penghapusan Kekerasan Dalam Rumah

Anak Agung Istri Ari Atu Dewi, 2013, "Perempuan Bali Dalam Hukum Adat : Suatu Analisis Gender" dalam buku Kembang Rampai Perempuan Bali, Pusat Studi Wanita dan Perlindungan Anak Universitas Udayana, hlm.176.

5 Waluyadi, Hukum Perlindungan Anak, Mandar Maju, Bandung, 2009, hlm.1.

6 Peter Salim dan Yeni Salim, 1997, Kamus Bahasa Indonesia Kontemporer, Jakarta: Modern English Pres, hlm.716.
Tangga, khususnya dalam Pasal 1 ayat (1) menyatakan bahwa kekerasan dalam rumah tangga adalah setiap perbuatan terhadap seseorang terutama perempuan yang berakibat timbulnya kesengsaraan atau penderitaan secara fisik, seksual, psikologi, dan/atau penelantaran rumah tangga termasuk ancaman untuk melakukan perbuatan, pemaksaan, atau perampasan kemerdekaan secara melawan hukum dalam lingkup rumah tangga. Selanjutnya dalam Pasal 1 Peraturan Menteri Negara Pemberdayaan Perempuan Dan Perlindungan Anak Republik Indonesia Nomor 01 Tahun 2010 secara tegas menyatakan bahwa kekerasan adalah setiap perbuatan secara melawan hukum dengan sarana ataupun tanpa menggunakan sarana yang dapat menimbulkan bahaya bagi nyawa dan badan serta berakibat hilangnya kebebasan (hak) seseorang. Selanjutnya Kekerasan terhadap perempuan dapat dipahami bahwa setiap tindakan yang dilakukan selalu berdasarkan pada perbedaan jenis kelamin yang mengakibatkan kesengsaraan atau penderitaan bagi kaum perempuan. Kekerasan tersebut dapat berupa kekerasan secara fisik, seksual atau psikologis, termasuk juga ancaman dari tindakan tertentu, perampasan kebebasan kaum perempuan secara sewenang-wenang, yang dapat terjadi di ranah publik ataupun dalam kehidupan pribadinya.

\subsubsection{Konsep standar Pelayanan minimal}

Berdasarkan Peraturan Menteri Negara Pemberdayaan Perempuan Dan Perlindungan Anak Republik Indonesia Nomor 01 Tahun 2010, dalam Pasal 1 angka 1 secara tegas dinyatakan bahwa Standar Pelayanan Minimal yang selanjutnya 
disebut SPM merupakan tolok ukur kinerja pelayanan unit yang melakukan pelayanan terpadu untuk memberikan pelayanan baik berupa penanganan laporan ataupun pengaduan, pelayanan kesehatan, pelayanan rehabilitasi sosial, pelayanan penegakan dan bantuan hukum, pelayanan pemulangan dan reintegrasi sosial bagi perempuan dan anak yang menjadi korban tindak kekerasan.

Adapun jenis-jenis Standar Pelayanan Minimal (SPM) yang dapat diberikan oleh Pemerinatah Kabupaten kepada pihak perempuan dan anak yang menjadi korban kekerasan meliputi 5 (lima) jenis layanan yaitu :

1. Layanan dibidang penanganan laporan atau pengaduan korban kekerasan

2. pelayanan kesehatan bagi perempuan dan anak korban kekerasan;

3. Layanan di bidang rehabilitasi sosial;

4. Layanan terhadap penegakan dan bantuan hukum korban kekerasan; dan

5. Layanan pemulangan dan reintegrasi sosial bagi perempuan dan anak korban kekerasan. $^{7}$

\subsection{Tujuan dan Manfaat Penelitian} Tujuan penelitian sebagai berikut :

1. Untuk mengetahui dasar kewenangan Pemerintah Daerah Kabupaten Badung dalam pemberian standar pelayanan bagi perempuan dan anak korban kekerasan.

2. Untuk mengetahui bentuk-bentuk standar pelayanan yang diberikan

Lihat Lampiran 2 Peraturan Menteri Negara Pemberdayaan Perempuan Dan Perlindungan Anak Republik Indonesia Nomor 01 Tahun 2010 Tentang Standar Pelayanan Minimal Bidang Layanan Terpadu Bagi Perempuan Dan Anak Korban Kekerasan. untuk perempuan dan anak korban tindak kekerasan.

\subsection{Manfaat penelitian dapat di bagi dua (2) meliputi :}

1. Manfaat teoritis

Penulisan karya ilmiah ini, diharapkan dapat bermanfaat secara teoritis yaitu bahwa dengan karya ilmiah ini dapat memberikan sumbangan bagi pembangunan Hukum khususnya mengenai pembangunan hukumterkait dengan perlindungan dan pemberian pelayanan korban kekerasan.

2. Manfaat praktis

Karya ilmiah ii diharapkan dapat memberikan manfaat teoritis yaitu dapat memberi sumbangan pemikiran kepada pihak- pihak yang terlibat dalam pemberian Standar Pelayanan Minimal terhadap Perempuan Dan Anak Korban Kekerasan.

\section{METODE PENELITIAN}

Dalam penulisan karya ilmiha ini, metode penelitian yang digunakan adalah metode penelitian normative. Menurut Peter mahmud Marzuki, bahwa penelitian hukum merupakan suatu proses untuk menemukan aturan hukum, prinsip-prinsip hukum, maupun doktrin-doktrin hukum untuk menjawab isu hukum yang dihadapi. ${ }^{8}$ Selanjutnya menurut Morris L. Cohen dan Kent C. Olson mengemukakan bahwa "Legal research is an essential component of legal practice. It is the process of finding the law that governs an activity and materials that explain or analyze that law". " Soerjono

\footnotetext{
Peter Mahmud Marzuki, 2005, Peneitian Hukum, Cetakan ke-1, Kencana, Jakarta, hlm.35.

9 Morris L. Cohen dan kent C. Olson, 2000, Legal Research In A Nutshell, Seventh Edition, ST. Paul, Minn, West Group, hlm.1.
} 
Soekanto juga mengemukakan 2 (dua) model metode penelitian hukum yaitu penelitian hukum normatif dan penelitian hukum sosiologis atau empiris. ${ }^{10}$ Penelitian hukum Normatif disebut juga sebagai penelitian hukum doktrinal atau penelitian hukum perpustakaan. Sebagai penelitian hukum doctrinal, karena penelitian ini dilakukan untuk meneliti peraturan-peraturan yang tertulis, sedangkan disebut sebagai penelitian perpustakaan atau studi dokumen karena penelitian ini lebih banyak dilakukan perpustakaan atau studi dokumen. ${ }^{11}$ Dalam karya illmiah ini focus untuk membedah permasalahan yang terkait dengan kajian pada pengaturan standar pelayanan bagi korban kekerasan, bentuk bentuk pelayanan serta mengkaji prosedur pelaksanaan dalam pemberian pelayanan pada perempuan dan anak korban kekerasan.

\section{HASIL DAN PEMBAHASAN}

\subsection{Dasar Kewenangan Pemerintah} Daerah Kabupaten Badung Dalam Pemberian Standar Pelayanan Minimal Bagi Perempuan Dan Anak Korban Kekerasan.

Pada dasarnya Kewenangan adalah kekuasaan yang bersifat formal, yang berasal dari kekuasaan legislative yaitu kekeuasaan yang diberikan oleh UndangUndang. ${ }^{12}$ Terkait dengan Perlindungan perempuan dan anak korban kekerasan, pemberian bentuk-bentuk standar minimal

10 Soerjono Soekanto, 1986, Pengantar Penelitian Hukum, Universitas Indonesia (UI) Press), Jakarta, hlm.51.

11 Bambang Waluyo, 1991, Penelitian Hukum Dalam Praktek, Sinar Grafika, jakarta, hlm.31.

12 Prajudi Atmosudirjo,1994, Hukum Administrasi Negara, Cetakan Kesepuluh, Ghalia Indonesia, Jakarta, hlm.78. telah diatur secara yuridis dalam peraturan perundang-undagan. Sebagaimana dilakatan oleh P. Nicolai bahwa kewenangan itu dapat diartikan sebagai kemampuan untuk melakukan tindakan hukum tertentu (yaitu tindakan-tindakan yang dimaksudkan untuk menimbulkan akibat-akibat hukum, dan mencakup mengenai timbul dan lenyapnya akibat hukum) $)^{13}$. Pemahaman yang demikian menempatkan pemahaman pada bahwa hak berisikan kebebasan untuk melakukan tindakan tertentu atau menuntut pihak lain untuk melakukan suatu tindakan tertentu, sedangkan kewajiban berisikan keharusan untuk melakukan tindakan tertentu. Mendasarkan pada pendapat P Nicolai, Pemerintah Kabupaten Badung dalam melakukan tindakan hokum dengan melakukan pemberian standar pelayanan minimal sebagai bentuk suatu kewajiban pemerintah untuk memberikan perlindungan terhadap perempuan dan anak yang menjadi korban tindak kekerasan. Dalam melakukan perlindungan hukum terhadap perempuan dan anak korban kekerasan, Pemerintah Kabupaten Badung mendasarkan kewenangannya sesuai dengan Pasal 28C ayat (3) Undang-Undang Dasar Negara Republik Indonesia Tahun 1945 mengamanatkan bahwa setiap orang mempunyai hak untuk kemajuan dirinya dan memperjuangkan haknya secara kolektif untuk membangun masyarakat, bangsa dan negaranya. Pemahaman ini mengandung makna bahwa setiap orang baik laki laki maupun perempuan mempunyai hak yang sama untuk melakukan upaya- upaya agar dapat mengangkat harkat dan martabat

Ridwan HR, 2006, loc.cit. 
dirinya baik dengan bekerja maupun dengan berusaha dengan maksud untuk meningkatkan kualitas hidupnya serta ikut berpartisipasi untuk membangun diri, keluarga, masyarakat dan bangsanya.

Selanjutnya dalam UU No. 39 Tahun 1999 tentang Hak Asasi Manusia khususnya dalam Pasal 45 menyatakan hak wanita adalah termasuk hak asasi manusia. Selanjutnya dalam Pasal 52 ayat (1) menyatakan setiap anak berhak atas perlindungan oleh orang tua, keluarga, masyarakat dan negara. Pada ayat (2) dinyatakan hak anak adalah hak asazi manusia dan untuk kepentingannya hak anak itu diakui dan dilindungi oleh hukum bahkan sejak dalam kandungan. Berdasarkan pengakuan dalam HAM bahwa hak wanita dan hak anak adalah hak asasi manusia.

Secara spesifik, Di Kabupaten Badung, kewenangan dalam memberikan standar pelayanan minimal terhadap perempuan dan anak korban kekerasan telah diatur dalam Peraturan Daerah Kabupaten Badung Nomor 15 Tahun 2013, yang dengan tegas menyatakan bahwa terhadap perempuan dan anak yang mendapatkan kekerasan wajib mendapat perlindungan. Dalam Pasal 9 dengan tegas dinyatakan jenis standar pelayanan yang diterapkan oleh Pemerintah Kabupaten Badung yaitu :

a. penangananpengaduan/laporanKorban Kekerasan terhadap Perempuan dan Anak.

b. pelayanan kesehatan bagi Perempuan dan Anak Korban Kekerasan.

c. rehabilitasi Sosial bagi Perempuan dan Anak Korban Kekerasan;

d. penegakan dan bantuan hukum bagi Perempuan dan Anak Korban Kekerasan; dan

e. pemulangan dan reintegrasi sosial bagi Perempuan dan Anak Korban Kekerasan.

Selanjutnya dalam Pasal 10 dapat dipahami bahwa yang menjadi indikator kinerja unit pelayanan terpadu adalah :

a. bahwa perempuan dan anak yang merupakan korban tindak kekerasan dipastikan mendapat layanan penanganan pengaduan oleh petugas yang terlatih.

b. Bahwa Perempuan dan Anak Korban Kekerasan dipastikan mendapatkan layanan kesehatan oleh tenaga kesehatan terlatih di Puskesmas maupun di Rumah Sakit;

c. cakupan layanan Rehabilitasi Sosial yang diberikan oleh petugas Rehabilitasi Sosial yang terlatih di dalam unit pelayanan terpadu;

d. cakupan layanan bimbingan rohani yang diberikan oleh petugas bimbingan rohani terlatih;

e. pelaksanaan penegakan hukum mulai dari tingkat penyidikan sampai dengan putusan pengadilan atas kasus-kasus Kekerasan terhadap Perempuan dan Anak;

f. cakupan Perempuan dan Anak Korban Kekerasan yang mendapatkan layanan bantuan hukum;

g. mendapatkan layanan Pemulangan bagi Perempuan dan Anak yang menjadi Korban Kekerasan; dan

h. cakupan layanan reintegrasi sosial bagi Perempuan dan Anak Korban Kekerasan.

Berdasarkan paparan diatas jelas, Kewenangan Pemerintah Kabupaten Badung dalam penerapan SPM terhadap perempuan dan anak korban kekereasan mendasarkan pada Perda nomor 15 tahun 
2013. Oleh karena itu SPM wajib dimiliki oleh pemerintah daerah yang bergerak di bidang pelayanan terhadap perempuan dan anak korban kekerasan. Pelayanan dengan berpedoman pada SPM wajib diberikan kepada korban apabila terbukti perempuan dan anak itu memang mendapat perlakuan kekerasan dan pemberian pelayanan terhadap perempuan dan anak korban kekerasan tersebut merupakan urusan wajib yang memang mutlak didapat oleh korban kekerasan.

\subsection{Bentuk-Bentuk Standar Pelayanan Yang Diberikan Oleh Pemerintah Daerah Kabupaten Badung.}

Sesuai dengan prinsip otonomi daerah, bahwa Pemerintah Daerah diberi kewenangaannya untuk menyelenggarakan pemerintannya untuk mencapai efesiensi dan efektifitas pemerintahan di daerah. Secara sederhana pemaknaan otonomi sebagaimana dikemukakan oleh logeman yang di kutip oleh Y.W. Sunidhia ${ }^{14}$ yaitu kebebasan dan kemandirian tetapi bukan kemerdekaan. Selanjutnya J. Wajong sebagaimana dikutip oleh Lukman Hakim ${ }^{15}$ juga mengutarakan bahwa otonomi merupakan kebebasan untuk memelihara dan memajukan kepentingan daerah, dengan menggunakan keuangan dan menentukan hukum sendiri serta pemerintahan sendiri. Lebih lanjut Lukman Hakim $^{16}$ menyatakan bahwa Apabila

14 Y.W. Sunindhia, 1987, Praktek Penyelenggaran Pemerintahan di Daerah, Bina Aksara Jakarta, hlm.35.

15 Lukman Hakim, 2012, Filosofi Kewenangan Organ Lembaga Daerah Perspektif Teori Otonomi \& Desetralisasi dalam Penyelenggaraan Pemerintahan Negara Hukum dan Kesatuan, Setara Press Malang hlm.35.

$16 \quad$ Ibid, hlm.37. otonomi diartikan sebagai segala tugas yang ada di daerah yang harus dikerjakan oleh Pemerintah Daerah, dimana melekat kewenangan yang berupa kekuasaan, hak dan kewajiban untuk menjalankan tugasnya.

Dalam memberikan standar pelayanan minimal berdasarkan prinsip otonomi, Pemerintah Daerah Kabupaten Badung mempunyai kewenangan untuk hal tersebut yangdalampelaksanaannyatetapberpedoman pada Peraturan hukum yang ada. Terkait dengan bentuk-bentuk standar pelayanan yang diberikan Pemerintah Kabupaten Badung telah diatur dalam Peraturan Daerah Kabupaten Badung Nomor 15 Tahun 2013 Tentang Perlindungan Perempuan dan Anak Korban Kekerasan. Dalam Pasal 9 Peraturan Daerah Kabupaten Badung Nomor 15 Tahun 2013 ditegaskan bahwa standar pelayanan yang diterapkan oleh Pemerintah Kabupaten Badung adalah :

a. penangananpengaduan/laporanKorban Kekerasan terhadap Perempuan dan Anak;

b. pelayanan kesehatan bagi Perempuan dan Anak Korban Kekerasan;

c. rehabilitasi Sosial bagi Perempuan dan Anak Korban Kekerasan;

d. penegakan dan bantuan hukum bagi Perempuan dan Anak Korban Kekerasan; dan

e. pemulangan dan reintegrasi sosial bagi Perempuan dan Anak Korban Kekerasan.

Sebagaimana disebutkan dalam Pasal 9 Peraturan Daerah Kabupaten Badung Nomor 15 Tahun 2013 yang dengan tegas mengatur mengenai standar pelayanan minimal yang harus dilakukan oleh Pemerintah Daerah Kabupaten Badung dalam menangani korban kekerasan baik perempuan mauupun 
anak, namun demikian perlu juga dijelaskan mengenai mengenai upaya yang dapat dilakukan untuk menjamin kualitas layanan dasar yang akan diterapkan. Untuk menjamin kualitaslayanandasardimaksudmakapenting untuk dibuat indikator kinerja yang meliputi: pertama, Pemeintah Daerah Kabupaten perlu mempersiapkan petugas yang terlaith di dalam unit pelayanan terpadu terkait dengan tenaga untuk menangani penanganan laporan atau pengaduan korban kekerasan serta petugaas dapat menindaklanjuti laporan korban dimaksud. Kedua, Ketersediaan tenaga terlatih baik di Puskesmas maupun di rumah sakit terkait dengan pelayanan di bidang kesehatan. Pelayanan kesehatan ini merupakan pelayanan yang meliputi aspek promotif, preventif dan rehabilitasi yang hanya dapat dilakukan oleh tenaga terlatih seperti dokter spesialis, perawat maupun bidan. Ketiga, cakupan rehabilitasi social yang juga termasuk pemberian bimbingan rohani yang diberikan oleh tenaga petugas yang terlatih. Dalam konteks ini pemerintah Daerah Kabupaten berkewajiban untuk memenuhi standar pelayanan tersebut. Keempat, Indikator penegakan dan bantuan hukum pun harus juga disiapkan oleh Pemerintah Daerah Kabupaten sebagai wujud pemberian layanan dasar kepada perempuan dan anak korban kekerasan. Pada prinsipnya Penegakan hukum dapat dipahami tindakan aparat yang diberikan kewenanggan oleh pemerintah untuk melakukan tugas dan fungsinya sebagai penegak hukum. Selanjutnya pemahaman bantuan hukum adalah segala sesuatu yang berkaitan dengan aspek hukum dalam proses peradilan pidana maupun perdata. Dalam konteks ini Pemerintah Daerah Kabupaten berkewajiban untuk menyediakan tenaga yang terlatih untuk itu. Kelima, Pemulangan dan Reintegrasi sosial, dalam konteks ini dapat dipahami bahwa pemulangan dan reintegrasi merupakan upaya mengembalikan korban ke daerah asal untuk dapat dikembalikan kepada keluarga inti atau masyarakat setempat. Dalam hal ini juga diperlukan untuk menyediakan petugas terlatih untuk dapat melakukan layanan dimaksud.

Mendasarkan pada hasil penelitian, bahwa dalam menerapkan standar pelayanan minimal dimaksd ada beberapa kendala yang dihadapi yaiyu :

1. Bahwa dalam memberikan pelayanan khusunya penanganan laporan atau pengaduan yang masih banyak mengalami kendala khususnya terbatasnya petugas yang menerima pengaduan serta belum memiliki pengalaman khususnya dalam penerimaan pengaduan. Seperti misalnya hanya melakukan pencatatan saja tanpa disertai dengan rasa empati, bahkan tidak ditindaklanjuti dengan cepat.

2. Dalam memberikan pelayanan kesehatan bagi korban, sangat dibutuhkan spesialisasi khusunya tenaga dokter, seperti dokter ahli forensic, psikolog, dan tenaga konseling yang terlatih. Kendala yang dihadapi adalah bahwa psikolog dan tenaga konseling yang terlatih masih sangat terbatas di Kabupaten Badung.

3. Layanan terhadap rehabilitasi social jugamengalamikendalayaituminimnya jumlah pendamping bagi korban tindak kekerasan. Selain itu sangat minim juga sarana dan prasarana rehabilitasi sosial seperti ruangan konseling dan 
biaya oprasional. Selanjutnya Rumah perlindungan social juga sangat minim yang khusunya menampung korban kekerasan perempuan dan anak.

4. Mengenai layanan penegakan hukum dan bantuan hukum juga mengalami kendala yaitu masih terbatasnya pemahaman aparat penegak hukum terkait dengan perlindungan perempuan dan anak khusunya korban kekerasan. Selanjutnya masih terbatasnyapengacara/advokad yang dapat memberikan layanan gratis (Cuma-Cuma), bahkan korban kekerasan seringkali tidak paham bahwa mereka juga mempunyai hak untuk mendapatkan pendampingan hukum.

5. Pelayanan pemulangan dan reintegrasi social juga menemukan kendala yaitu terbatasnya biaya yang tersedia dan masih beum terkordinasi. Sebagaimana diketahui bersama dalam melakukan pemulangan dibutuhkan proses panjang untuk menentukan instansi mana yang akan membiayai proses pemulangan korban dimaksud. Dalam permasalahan pemulangan korban kekerasan dari daerah debarkasi dan dari daerah penerima ke daerah asal juga memerlukan dana yang cukup besar mulai dari penyiapan keluarga sampai kesiapan korban untuk kembali ke dalam keluarganya.

Delngan diketahuinya kendalakendala dalam penanganan korban kekerasan khususnya terhadap kewajiban pemerintah dalam memberilkan standar pelayanan minimal terhadap perempuan dan anak korban kekerasan, maka pemerintahan Daerah Kabupaten Badung dapat sesegera mungkin berbenah untuk dapat terpenuinya hak-hak korban kekerassan, sebagaimana disebut di atas adalah 5 (lima) pelayanan dasar yang harus didapat oleh perempuan dan anak korban kekerasan.

\section{PENUTUP}

\subsection{Simpulan}

Berdasarkan uaraian sebelumnya, dapat ditarik simpulan sebagai berikut :

4.1.1 bahwa yang menjadi dasar kewenangan Pemerintah Daerah Kabupaten Badung untuk pemberian standar pelayanan terhadap kaum perempuan dan anak yang menjadi korban kekerasan adalah mendasarkan pada Peraturan daerah Nomor 15 TAhun 2013 tentang Perlindungan Perempuan dan Anak Korban Kekerasan. Selain itu kewenangan Pemerintah Kabupaten Badung dalam pemberian standar pelayanan kepada perempuan dan anak, juga mendasarkan pada berlakunya UU No. 23 tahun 2004 tentang Penghapusan Kekerasan dalam Rumah Tangga, UU nomor 35 Thun 2014 tentang Perubahan atas Undang-Undang Nomor 23 Tahun 2002 tentang Perlindungan Anak, UU tentang Tindak Pidanan Perdagangan Orang serta Peraturan Menteri Pemberdayan Perempuan dan Perlindungan Anak No.01 TAhun 2010 serta Permen Pemberdayaan Perempuan dan Perlindungan Anak No 5 Tahun 2010 tentang Pembentukan dan Pengembangan Pusat Pelayanan Terpadu.

4.1.2 bahwa terkait dengan bentuk-bentuk standar pelayanan yang diberikan Pemerintah Daerah Kabupaten Badung 
bagi perempuan dan anak korban kekerasan yaitu berdasarkan pada Peraturan Daerah Nomor 15 Tahun 2013 tentang Perlindungan Perempuan dan Anak Korban Kekerasan, dalam Peraturan Daerah tersebut, ada lima (5) bentuk standar pelayanan minimal yaitu :

a. Standar Pelayanan Minimal mengenai penanganan pengaduan atau laporan Korban Kekerasan;

b. Standardalampemberianpelayanan kesehatan terhadap Perempuan dan Anak yang menjadi Korban Kekerasan;

c. Pemberian standar layanan rehabilitasi sosial bagi korban Perempuan dan Anak.

d. Standar mengenai layanan penegakandanbantuanhukumyang diberikan Pemerintah Kabupaten Badung untuk Perempuan dan Anak Korban Kekerasan; dan

e. Pemberian Layanan kepada Perempuan dan anak terkait dengan pemulangan dan reintegrasi sosial. Dengan diatur secara tegas dalam Perda tentang standar pelayanan inimal, maka menjadi kewajiban Pemerintah Daerah Kabupaten Badung untuk memenuhi dan menyediakan setiap layanan kepada korban kekerasan khusunya perempuan dan anak sesuai dengan standar yang telah ditetapkan.

\subsection{Saran}

Sesuai dengan simpulan di atas, maka dapat disarankan:

4.2.1 Bahwa untuk mengoptimalkan pelaksanaan penanganan Perempuan dan anak korban kekerasan, maka Pemerintah Daerah Kabupaten Badung agar melakukan pengawasan dalam bentuk pemantauan dan evaluasi yang nantinya bertujuan untuk mengetahui perkembangan pelaksanaan Pelayanan yang telah diberikan dan untuk mengetahui capaian kinerja Pemerintah Daerah Kabupaten dalam penanganan perempuan dan anak korban kekerasan.

4.2.2 Bahwa untuk lebih cepat penanganan perempuan dan anak korban kekerasan maka Pemerintah perlu melibatkan peran serta masyarakat desa dengan membentuk Pusat Pelayanan Terpadu di desa.

\section{DAFTAR PUSTAKA}

Arif Gosita, 1989, Masalah Perlindungan Anak, Akademika Pressindo, Jakarta.

Ari Atu Dewi, Anak Agung Istri, 2013, "Perempuan Bali Dalam Hukum Adat: Suatu Analisis Gender" dalam buku Kembang Rampai Perempuan Bali, Pusat Studi Wanita dan Perlindungan Anak Universitas Udayana.

Bambang Waluyo, 1991, Penelitian Hukum Dalam Praktek, Sinar Grafika, jakarta. Indroharto, 1993, Usaha memahami UndangUndang tentang Peradilan Tata Usaha Negara, Pustaka Harapan, Jakarta.

Jum Anggriani, 2012, “Hukum Adminsitrasi Negara”, Graha Ilmu, Yogyakarta.

Lukman Hakim, 2012, Filosofi Kewenangan Organ Lembaga Daerah Perspektif Teori Otonomi \&Desetralisasi dalam Penyelenggaraan Pemerintahan Negara Hukum dan Kesatuan, Setara Press Malang. 
Morris L. Cohen dan kent C. Olson, 2000, Legal Research In A Nutshell, Seventh Edition, ST. Paul, Minn, West Group. Mansour Fakih, 1997, Analisis Gender dan

Transformasi Sosial, Pustaka Pelajar Offset.

Marhaendra Wija Atmaja, Gede, 2012, "Politik Pluralisme Hukum dalam Pengakuan Kesatuan Masyarakat Hukum Adat dengan Peraturan Daerah", Disertasi Doktor, Program Doktor Ilmu Hukum Fakultas Hukum Universitas Brawijaya, Malang.

Prajudi Atmosudirjo,1994, Hukum Administrasi Negara, Cetakan Kesepuluh, Ghalia Indonesia, Jakarta.

Peter Salim dan Yeni Salim, 1997, Kamus Bahasa Indonesia Kontemporer, Jakarta: Modern English Press.

Peter Mahmud Marzuki, 2005, Peneitian Hukum, Cetakan ke-1, Kencana, Jakarta.

Philipus M. Hadjon, et.al, 2011, Pengantar Hukum Administrasi Indonesia, Introduction to the Indonesian Administrative law, Gadjah Mada University Press, Yogyakarta.

Ridwan HR, 2006, Hukum Administrasi Negara, PT. Raja Grafindo Persada, Jakarta.

Sunindhia, Y.W 1987, Praktek Penyelenggaran Pemerintahan di Daerah, Bina Aksara Jakarta.

Soerjono Soekanto, 1986, Pengantar Penelitian Hukum, Universitas Indonesia (UI) Press), Jakarta.

Sadjijono, H, 2011, Bab-Bab Pokok Hukum Administrasi, Cetakan II, Edisi II, Laksbang Pressindo, Yogyakarta.

Waluyadi, 2009, Hukum Perlindungan Anak, Mandar Maju, Bandung.
Yudhi Setiawan, 2009, Instrumen Hukum campuran (gemeenscapelijkrecht) dalam Konsolidasi Tanah, PT. Raja Grafindo Persada, Jakarta.

Undang-Undang Undang-Undang Dasar Negera Republik Indonesia Tahun 1945.

Undang-Undang Nomor 39 tahun 1999 tentang Hak Asasi Manusia.

Undang-Undang Nomor 35 Tahun 2014 tentang Perubahan atas UndangUndang 23 Tahun 2002 tentang Perlindungan Anak.

Undang-Undang Nomor 23 tahun 2004 Tentang Penghapusan Kekerasan Dalam Rumah Tangga.

Undang-Undang Nomor 21 Tahun 2007 tentang Pemberantasan Tindak Pidana Perdagangan Orang

Peraturan Menteri Negara Pemberdayaan Perempuan dan Perlindungan Anak Nomor 5 Tahun 2010 tentang Panduan Pembentukan Pusat Pelayanan Terpadu.

Peraturan Daerah Kabupaten Badung Nomor 15 Tahun 2013 tentang Perlindungan Perempuan dan Anak Korban Kekerasan. 